ANNUAL PROGRESS REPORT FOR CONTRACT AT(1I-1) 1793

\author{
"EFFECTS OF ULTRAVIOLET RADIATION ON ALGAE:
}

MECHANISMS OF INACTIVATION AND REPAIR"

Period covered by report: May 1, 1970 to April 30, 1971

Prepared by

Gary D. Smali

Principal Investigator

Department of Biochemistry

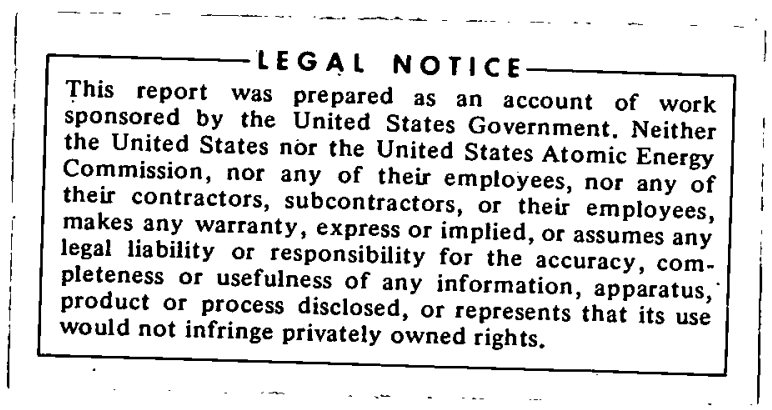

\title{
School of Medicine
}

University of South Dakota

Vermilion, South Dakota

57069 


\section{DISCLAIMER}

This report was prepared as an account of work sponsored by an agency of the United States Government. Neither the United States Government nor any agency Thereof, nor any of their employees, makes any warranty, express or implied, or assumes any legal liability or responsibility for the accuracy, completeness, or usefulness of any information, apparatus, product, or process disclosed, or represents that its use would not infringe privately owned rights. Reference herein to any specific commercial product, process, or service by trade name, trademark, manufacturer, or otherwise does not necessarily constitute or imply its endorsement, recommendation, or favoring by the United States Government or any agency thereof. The views and opinions of authors expressed herein do not necessarily state or reflect those of the United States Government or any agency thereof. 


\section{DISCLAIMER}

Portions of this document may be illegible in electronic image products. Images are produced from the best available original document. 


\section{SCOPE OF THE PROJECT}

The objective of this project is to study the mechanisms for the repair of ultraviolet light-induced damage in the DNA of model eukaryotic cells, the single-celled green algae. There are three facets to our project that are currently underway. First is a study of the photoreactivating enzymes in algae. Second is the study of the induction and subsequent fate of pyrimidine dimers in the algae. Third is a study of enzymes in the alga, Chiamydomonas reinhardi, which may be involved in the excision-repair mechanism.

\section{SIGNIFICANT RESULTS OBTAINED}

\section{A. Photoreactivating Enzymes}

Using the Hemophizus influenzae transformation assay, we have detected photoreactivating enzyme in both green and bleached cells of Euglena gracilis as well as Chramydomonas. We have' purified the enzyme from Euglena over 400-fold. At this stage of purification there is no detectable nuclease activity under conditions of the photoreactivating enzyme assay. This is a necessary prerequisite before any meaningful catalytic measurements of the photoreactivating enzyme can be made. For other details of the enzyme see CoO-1793-6. 
Indirect studies have suggested that chloroplasts may contain photoreactivating enzyme activity. We have isolated chloroplasts from Euglena and found photoreactivating enzyme activity in extracts prepared from these chloroplasts. The specific activity of this enzyme does not change upon further purification by flotation in sucrose, suggesting that the activity may be an inherent part of the chloroplasts and not a contaminant (see (00-1793-3). However, further work is necessary to unequivocally establish this point.

B. Detection of Ultraviolet light-Induced Photoproducts in A. Zgae DNA

We have attempted to label the DNA of Euglena and ChIamydomonas highly with radioactive thymine and thymidine with little success. Addition of cold deoxynucleotides did not increase the uptake of thymine. Inhibition of endogenous synthesis of TMP with sulfanilamides was also not successful in increasing the uptake of thymine.

Thus, we turned to ${ }^{32} \mathrm{P}$ as a label since DNA with high specific activity can be obtained by growth in ${ }^{32} \mathrm{p}$-orthophosphate. This required a quantitative method for studying ${ }^{32} \mathrm{P}-1$ abeled photoproducts in irradiated DNA. We have worked out a method for isolating pyrimidine dimers from enzymic digests of irradiated ${ }^{3 .}$ P-labeled DNA (Smal1 and Sparks, in press, CO0-1793-4). At present we are applying this method to wild-type and UV-sensitive mutants of Chzamydomonas reinhardi.

In addition to its use for our problem, this method opens the door for the study of acid and alkali labile photoproducts in 
irradiated DNA.

C. Enzymes of DNA Metabolism in ChZamydomonas

A thorough understanding of repair mechanisms will come only after isolation of the pertinent enzymes and reconstruction of the repaix process in vitro. As a start toward this goal we have begun a study of enzymes in Chramydomonas that may have a role in repair and replication of DNA.

We have partially purified a DNase with a high specificity toward single-stranded DNA. The enzyme has a pH optimum of about 8.8 and does not require an exogenous metal for activity, though it is inhibited by fairly low concentrations of EDTA. Robert B. Sparks, a graduate student, is presently undertaking the purification and study of the properties of this enzyme.

D. Percent Time Devoted to Project

1. Gary D. Sma11, Principal Investigator-50\% of time for 12 months

2. Mrs. Soojae. Zeon, Technician-full time for 10 months

3. Mr. Robert B. Sparks, graduate student-50\% of time for 12 months

E. Bibliography

1. Sparks, R.B. and Sma11, G.D., Abstracts 13 th West Central States Biochemistry Conference, 1970

"Isolation of Pyrimidine Dimers from an Enzyme Hydrolysate of UV-irradiated "DNA" 
AT $(11-1) 1793$ COO-1793-5

2. Smal1, G.D. and Sparks, R.B., Anal. Biochem., In Press (1971)

"Isolation of U1traviolet Light-Induced Pyrimidine Dimers from Enzymic Hydrolysates of DNA"

3. Small, G.D., manuscript in preparation "Partial Purification of Photoreactivating Enzyme from Euglena gracilis" 